\title{
Elevated pCO2 does not impair performance in autotomised individuals of the intertidal predatory starfish Asterias rubens (Linnaeus, 1758)
}

McCarthy, Ian; Whiteley, Nia; Fernandez, Wellington; Ragagnin, Marilia;

Cornwell, Tomas; Suckling, Coleen; Turra, Alexander

\section{Marine Environmental Research}

DOI:

10.1016/j.marenvres.2019.104841

Published: 01/01/2020

Peer reviewed version

Cyswllt i'r cyhoeddiad / Link to publication

Dyfyniad o'r fersiwn a gyhoeddwyd / Citation for published version (APA):

McCarthy, I., Whiteley, N., Fernandez, W., Ragagnin, M., Cornwell, T., Suckling, C., \& Turra, A. (2020). Elevated $p C O 2$ does not impair performance in autotomised individuals of the intertidal predatory starfish Asterias rubens (Linnaeus, 1758). Marine Environmental Research, 153, [104841]. https://doi.org/10.1016/j.marenvres.2019.104841

Hawliau Cyffredinol / General rights

Copyright and moral rights for the publications made accessible in the public portal are retained by the authors and/or other copyright owners and it is a condition of accessing publications that users recognise and abide by the legal requirements associated with these rights.

- Users may download and print one copy of any publication from the public portal for the purpose of private study or research.

- You may not further distribute the material or use it for any profit-making activity or commercial gain

- You may freely distribute the URL identifying the publication in the public portal ?

Take down policy

If you believe that this document breaches copyright please contact us providing details, and we will remove access to the work immediately and investigate your claim. 
1 Elevated $p \mathrm{CO}_{2}$ does not impair performance in autotomised individuals of the intertidal

2

3

4

5

6

7 a School of Ocean Sciences, Bangor University, Menai Bridge, Anglesey, LL59 5AB, United Kingdom,

8 b. School of Natural Sciences, Bangor University, Bangor, Gwynedd, LL57 2UW, United Kingdom,

9 c Oceanographic Institute, São Paulo University, São Paulo, São Paulo, 05508-120, Brazil,

10

11

12

\section{predatory starfish Asterias rubens (Linnaeus, 1758)}

Ian D. McCarthy ${ }^{\mathrm{a}}$, Nia M. Whiteley ${ }^{\mathrm{b}}$, Wellington S. Fernandez ${ }^{\mathrm{c}, *}$, Marilia N. Ragagnin ${ }^{\mathrm{c}}$, Tomas O. Cornwell ${ }^{\mathrm{a}}$, Coleen C. Suckling ${ }^{\mathrm{d}}$, Alexander Turra $^{\mathrm{c}}$

${ }^{\mathrm{d}}$ School of Fisheries, Animal and Veterinary Science, University of Rhode Island, Kingston, RI, 02881, USA

* Corresponding author: Laboratório de Manejo, Ecologia e Conservação Marinha, Departamento de Oceanografia Biológica, Instituto Oceanográfico, Universidade de São Paulo (USP), Praça do Oceanográfico, 191, 05508-120, São Paulo, SP, Brazil. E-mail address: fernandez@usp.br (W.S. Fernandez) 


\section{HIGHLIGHTS}

- Ocean acidification research requires further understanding on the interactions with other stressors

- We examined the combined effects of $p \mathrm{CO}_{2}$ and arm autotomisation on Asterias rubens

- Neither stressor affected mortality, growth, arm regeneration, righting time or arm calcium content

- Lipid content in the pyloric caeca increased in response to elevated $p \mathrm{CO}_{2}$

- A. rubens appears unaffected by short-term exposure to $p \mathrm{CO}_{2}$ levels predicted for 2100

\section{ABSTRACT}

The impacts of ocean acidification remain less well-studied in starfish compared to other echinoderm groups. This study examined the combined effects of elevated $p \mathrm{CO}_{2}$ and arm regeneration on the performance of the intertidal predatory starfish Asterias rubens, as both are predicted to come at a cost to the individual. A two-way factorial experiment ( $400 \mu$ atm vs $\sim 1000$ $\mu \mathrm{atm}$; autotomised vs non-automised individuals) was used to examine growth rates, lipid content (pyloric caeca and gonads), and calcium content (body wall) in both intact and regenerating arms, as well as subsequent effects on rate of arm regeneration, righting time (behaviour) and mortality over 120 days. Autotomised individuals tended to show lower (not significant), survival and growth. Elevated $p \mathrm{CO}_{2}$ had no effect on mortality, body growth, arm regeneration, righting time or arm calcium content. Lipid content was higher in the pyloric caeca, but not in the gonads, in response to elevated $p \mathrm{CO}_{2}$ irrespective of autotomisation. The results of the study suggest that adult $A$. rubens remain unaffected by increased $p \mathrm{CO}_{2}$ and/or arm autotomy for 120 days, although longer term experiments are necessary as the results indicated that survival, growth and calcification may be impaired with longer-term exposure to elevated $p \mathrm{CO}_{2}$.

Key-words: Global change; Water chemistry; Ocean Acidification; Asteroidea; growth; regeneration, Righting Time Response. 


\section{Introduction}

The acceleration of the release of anthropogenic carbon dioxide $\left(\mathrm{CO}_{2}\right)$ into the atmosphere and consequential absorption by the oceans has resulted in reductions in surface seawater $\mathrm{pH}$ and carbonate saturation $(\Omega)$ over the last 250 years (Doney et al., 2009; Feely et al., 2009). Since 2005, there has been considerable global research effort to predict how marine organisms, particularly those that calcify, will respond to the changes in seawater chemistry known as ocean acidification. Application of the RCP8.5 'business as usual' scenario, which predicts increases of $1000+\mu$ atm $p \mathrm{CO}_{2}$ and subsequent reductions in seawater $\mathrm{pH}$ by a further $0.3-0.4 \mathrm{pH}$ units by the end of the century (IPCC, 2014), has generally indicated negative biological and ecosystem effects (e.g. Browman, 2016; Kroeker et al., 2010, 2013; Nagelkerken and Connell, 2015). Although, as stated by Browman (2016), a broader perspective is required as there are many gaps in our knowledge about compensatory responses, such as calcification, adaptive responses and the interaction between simultaneous environmental changes, as well as the influence of life stages, season and nutritional condition. To date, it has been demonstrated that sensitivities to elevated $p \mathrm{CO}_{2}$ concentrations vary among taxa, species and populations (Kroeker et al., 2013; Przeslawski et al., 2015; Whiteley, 2011; Wittman and Pörtner, 2013). It is thought that species living in more environments that experience greater fluctuations in $\mathrm{pH}$ and temperature (e.g. vents, coastal shelf sea and the intertidal) may be more resilient to future environmental change due to their preadapted physiological capacities and plasticity (Collard et al., 2013; Hendriks et al., 2010; Whiteley et al., 2018).

Studies on the response of Echinodermata to near-future $p \mathrm{CO}_{2}$ conditions have tended to focus on echinoid sea urchins and stellate and ophiuroid brittlestars (e.g. Dupont et al., 2008, 2010b; Hu et al., 2014; Kroeker et al., 2010, 2013; Rodríguez et al., 2017; Ross et al., 2015; Suckling et al., 2015; Wood et al., 2008; 2010; 2011). Stellate asteroid starfish have received less attention until recently (e.g. Appelhans et al., 2012; 2014; Hu et al., 2018; Keppel et al., 2015), despite their important ecological role as carnivores in benthic marine ecosystems where they drive 
keystone predatory pressure and community structure (Calil et al., 2009; Freeman et al., 2001; Kayal el al., 2012; Menge, et al., 1999). Asteroids are structurally different from ophiuroids in that the arms have external skeletal support, and contain both gonads and pyloric caeca (digestive organs and nutrient reserves). Moreover, asteroids have a remarkable capacity to regenerate their arms after autotomy of up to $75 \%$ of their body mass in order to avoid predators, to replace damaged or infected appendages, or to recover from fishing disturbance (Lawrence, 2010; Ramsay et al., 2001b). Autotomy in most asteroid families is a common feature taking place along a single plane proximal to the disc resulting in the loss of an entire arm including body wall and viscera, amounting to a loss of $20 \%$ of their capacity to store nutrients and reproduce (Lawrence, 2010; Schram et al., 2011). The loss of an arm can compromise nutrient uptake by affecting the ability of the starfish to move and capture prey (Ramsay et al., 2001a). Regeneration can also come at a cost, due to the synthesis of new tissues, leading to a diversion of energy away from growth, nutrient stores and reproduction in the remaining, intact arms (Díaz-Guisado et al., 2006; Lawrence and Larrain, 1994; Ramsay et al., 2001a). Changing environmental conditions, such as elevations in seawater $p \mathrm{CO}_{2}$ have also been shown to reduce rates of growth and development during early life history stages, attributed to the costs associated with compensatory adjustments in body fluid $\mathrm{pH}$ and calcification. For instance, growth rates are restricted by elevated $\mathrm{CO}_{2}$ in the larvae of sea urchin Strongylocentrosus species (Stumpp et al., 2011, 2013), and in juvenile and larval stages of A. rubens (Appelhans et al., 2012, 2014; Hu et al., 2018; Keppel et al., .2015). These studies suggest competing demands for energy reserves for arm regeneration in starfish under conditions of elevated $p \mathrm{CO}_{2}$, although the combined effects of autotomy and elevated $p \mathrm{CO}_{2}(780 \mu \mathrm{atm}) \mathrm{had}$ no effect on the rate of arm regeneration or energy resources in adult tropical starfish Luidia clathrata after 97 days (Schram et al., 2011). As compensatory responses to elevated $\mathrm{CO}_{2}$ vary substantially among species within the same taxa (Dupont et al., 2010b; Kroeker et al., 2010; Stumpp et al., 2012), and as tropical species do not appear to augment their metabolic rates as much as temperate species in terms of adjustments to high $\mathrm{CO}_{2}$ (Kelley and Lunden, 2017), we 
were interested in establishing whether arm regeneration is more sensitive to elevated $\mathrm{CO}_{2}$ in temperate adult starfish species.

The purpose of the current study was to examine the combined effects of experimental autotomy in the common temperate starfish, Asterias rubens, exposed to the RCP8.5 $p \mathrm{CO}_{2}$ levels predicted for $2100(\sim 1000 \mu \mathrm{atm}$; IPCC, 2014). A. rubens is widely distributed in the northeast Atlantic Ocean from the mid-shore down to $650 \mathrm{~m}$ (Pearse et al., 1987) and is an important and voracious predator of benthic epifauna, such as barnacles, mussels and oysters, sometimes competing for food with commercial fish species (Anger et al., 1977; Sloan and Aldridge, 1981). We exposed adult $A$. rubens to elevated $p \mathrm{CO}_{2}$ in a two-way factorial design (ambient vs elevated $p \mathrm{CO}_{2}$; non-autotomised vs autotomised individuals) for 120 days. We were especially interested in the effects of these treatments on the opposing demands of increased compensation for elevated $p \mathrm{CO}_{2}$ and the costs associated with regeneration, in a laboratory-based situation where the food availability was standardised across treatments. To this end, we investigated rates of growth in both intact and regenerating arms, and examined associated changes in an important energy resource (lipids), which can constitute $30 \%$ of the dry weight of the pyloric caeca (Lawrence, 2010). We also determined changes in calcium content of the body wall of both intact and regenerating arms to assess whether calcification rates follow similar responses to those observed in ophiuroid brittlestars, such as Amphiura filiformis where elevated $p \mathrm{CO}_{2}$ increased calcium content of the regenerating arm (Wood et al., 2008). Finally, we observed righting responses to assess any subsequent effects on the behaviour or ability of the starfish to respond to challenging and stressful situations (e.g. Lawrence and Cowell, 1996). Overall, the study aimed to improve our understanding of whether an asteroid species living in rock pools from the mid-shore downwards and exposed to variable $p \mathrm{CO}_{2}$, but also with a remarkable ability to regenerate body parts, is susceptible to elevated $p \mathrm{CO}_{2}$, and whether there are any repercussions to energy resources and performance. 


\section{Materials and methods}

\subsection{Sampling, experimental design and acidification of natural seawater}

Sixty common starfish Asterias rubens L. were collected in February 2015 from the intertidal zone in the Menai Strait, North Wales, UK $\left(53^{\circ} 14^{\prime} \mathrm{N}, 04^{\circ} 09^{\prime} \mathrm{W}\right)$, placed in plastic buckets with seawater and transported back to the School of Ocean Sciences (SOS) at Bangor University (UK). In the laboratory, the starfish were placed in a stock tank $(120 \times 60 \times 30 \mathrm{~cm})$ supplied with flow-through seawater pumped onshore from the Menai Strait to acclimatize to the experimental conditions (salinity of $32,12^{\circ} \mathrm{C}, \mathrm{pH} 8.0,12 \mathrm{~h}$ Light: $12 \mathrm{~h}$ Dark photoperiod). After 21 days acclimatisation, the radius of the arm opposite the madreporite of each starfish was measured $( \pm 1 \mathrm{~mm})$ using Vernier callipers and each animal was blotted dry with absorbent paper towel, weighed $( \pm 0.01 \mathrm{~g})$ and placed individually into an experimental $3.5 \mathrm{~L}$ plastic jar (with holes all across the surface to allow flow-through of water) within the stock tank for a further 7 days acclimatisation. During acclimatisation and subsequent experimental exposure, starfish were fed ad libitum with live blue mussel Mytilus edulis. Thirty individuals (15 per treatment) had one arm autotomised, opposite to the position of the madreporite, along the single autotomy plane located at the base of the arm by applying pressure half way down the arm with a pair of pliers (Loh and Todd, 2012). Loss of haemolymph from the wound is minimal using this method due to rapid muscle contraction and clotting to form a wound epidermis (Hernroth et al., 2010).

The elevated $p \mathrm{CO}_{2}$ treatment used was based on the reduction of $0.3-0.4 \mathrm{pH}$ units (the 'business-as-usual' IPCC scenario) expected to occur by the end of the $21^{\text {st }}$ century (IPCC, 2014). Starfish were exposed to one of two $p \mathrm{CO}_{2}$ levels: ambient $p \mathrm{CO}_{2}(\sim 400 \mu \mathrm{atm})$ and elevated $p \mathrm{CO}_{2}$ ( $1000 \mu \mathrm{atm})$. Ambient $p \mathrm{CO}_{2}$ was achieved by bubbling air into a mixing tank $(350 \mathrm{~L})$ and elevated $p \mathrm{CO}_{2}$ was achieved in a separate mixing tank by controlling the flow of a gas mixture of air and pure $\mathrm{CO}_{2}$ via gas line restrictors and flow meters as detailed by Findlay et al. (2008). Water from the mixing tanks was pumped into two separate header tanks $(100 \mathrm{~L})$, one for each treatment, and from each header tank into the holding tanks (three per treatment) by gravity before running to 
waste. Temperature was controlled via an in-line thermostatic heater balanced against a chiller (details in Whiteley et al., 2018). Seawater parameters were measured following the methods outlined in Suckling et al. (2014) and Whiteley et al. (2018). In summary, pH, salinity and temperature were measured daily using a multi-parameter water analyser (Mettler Toledo SevenGo) and a pH probe (LE pH Electrode LE438-IP67) calibrated with NIST (National Institute of Standards and Technology) certified $\mathrm{pH}$ buffer solutions twice weekly. Phosphate and silicate were sampled monthly via GFF filtered seawater $(60 \mathrm{~mL})$ and analysed using a flow injection autoanalyser (Lachat 8500$)$. Seawater $(100 \mathrm{~mL})$ samples were collected in borosilicate glass bottles and $\mathrm{TCO}_{2}$ was immediately analysed (Ciba-Corning $\mathrm{TCO}_{2}$ Analyser, Olympic Analytical, UK). These parameters were then used to calculate $p \mathrm{CO}_{2}$ and carbonate saturation states $(\Omega)$ using and stored at $-20^{\circ} \mathrm{C}$ until analysis.

Acclimatised starfish were allocated to one of four treatments (15 starfish per treatment) in a fully orthogonal design: $p \mathrm{CO}_{2}(\sim 400 \mu \mathrm{atm} ; \sim 1000 \mu \mathrm{atm})$ and arm autotomisation (autotomised; non-autotomised). Three replicate holding tanks were used for each treatment, each with 5 autotomised and 5 non-autotomised starfish (Figure 1). At the end of the experiment (120 days), the starfish were dissected and the pyloric caeca and gonads from all the arms pooled and weighed to the nearest $0.01 \mathrm{~g}$. Samples from the pyloric caeca and gonadal tissues and from the arms were retained for analysis of lipid (see section 2.3) and calcium content (see section 2.4), respectively,

\subsection{Mortality, growth, arm regeneration and behaviour}


Mortality, growth, arm regeneration and righting behaviour were determined for all starfish on days $0,30,60,90$, and 120 days of the experimental exposures. Mortality was checked daily and expressed as mean cumulative mortality per replicate per 30 day time period. To evaluate body growth and arm regeneration, starfish were removed from the holding tanks, blotted dry with a paper towel for $30 \mathrm{~s}$, and immediately weighed $( \pm 0.01 \mathrm{~g})$. The starfish were then placed on a laminated sheet of $1 \mathrm{~mm}$ graph paper, photographed and the length of all arms measured using ImageJ (Abramoff et al., 2004). Regeneration capacity was calculated by dividing the length of the regenerating arm by the length of the longest arm at each experimental time. The 'righting time response' (RTR) was tested before measuring body mass and arm regeneration to prevent stressing the individuals. Starfish were placed upside down with the aboral surface downwards in an experimental aquarium maintained at the appropriate experimental conditions and the time taken to return the oral face to the substrate was recorded (Held and Harley, 2009; Joly-Turquin et al., 2009; Kleitman, 1941; Lawrence and Cowell, 1996). RTR was calculated as: RTR = 1,000/righting time (s; Watts and Lawrence 1990) where a higher RTR value indicates that the individual rights itself more quickly.

\subsection{Lipid energy content}

Lipid content of the pooled pyloric caeca and gonads collected from each of six randomlyselected starfish per treatment was determined using the sulpho-phospho-vanilline method modified by Torres et al. (2007). Tissue subsamples $(20 \mathrm{mg}$ ) were homogenized in ice cold $400 \mu \mathrm{l}$ deionized water, and extracted in a $40 \mu \mathrm{l}$ subsample by addition of $180 \mu \mathrm{l}$ chloroform:methanol solution (2:1). After centrifugation at $4^{\circ} \mathrm{C}$ for $20 \mathrm{~min}$ at $14,000 \mathrm{rpm}$ (Multispeed refrigerated centrifuge, RK121R, ALC), the lower chloroform phase was decanted and warmed at $60^{\circ} \mathrm{C}$ for approximately $40 \mathrm{~min}$. After cooling, $200 \mu \mathrm{l}$ of concentrated sulphuric acid was added and samples were incubated at $95^{\circ} \mathrm{C}$ for $10 \mathrm{~min}$. A sub-sample of $20 \mu \mathrm{l}$ was pipetted in triplicate into a microplate and $300 \mu 18 \mathrm{mM}$ phospho-vanillin added. Samples were incubated for 40 minutes at 
room temperature in the dark and then measured in a microplate reader (Multiscan FC, Thermo

Scientific) at a wavelength of $530 \mathrm{~nm}$ using cholesterol as standard. The lipid content in the pyloric caeca and gonad samples for each starfish was converted into energy equivalents using an enthalpy of combustion of $39.5 \mathrm{~kJ} \mathrm{~g}^{-1}$ (De Coen and Janssen, 1997), and expressed as mass-specific values $\left(\mathrm{kJ} \mathrm{mg}^{-1}\right.$ wet mass) and as whole-tissue values $\left(\mathrm{kJ} \mathrm{tissue}^{-1}\right)$.

\subsection{Calcium content}

At the end of the experiment calcium content was measured in the arm(s) of six randomlyselected starfish per treatment. Samples were taken from the left arm opposite to the position of the madreporite of all individuals and from the regenerating arm of the autotomised animals. Prior to sampling, each arm to be sampled was rinsed with distilled water, blotted dry, and approximately $30 \mathrm{mg}$ of intermediate part of arm (including ectoderm, calcareous plate and peritoneal epithelium tissues) was removed by dissection. Each sample was weighed $( \pm 0.01 \mathrm{~g})$, dried in an oven at $60^{\circ} \mathrm{C}$ for 24 hours and reweighed before digestion in $400 \mathrm{ml} 70 \%$ nitric acid at $42^{\circ} \mathrm{C}$ overnight. The total calcium content in each sample was then determined in a $4 \mathrm{ml}$ aliquot (x100 dilution) using a flame photometer (Sherwood Scientific Flame Photometer Model 410) and expressed as $\mu \mathrm{mol} \mathrm{Ca}{ }^{2+} \mathrm{mg}^{-}$ ${ }^{1}$ dry mass.

\subsection{Statistical analysis} (Levene's test) and data that did not meet these requirements were log-transformed [Body mass $=$ $\log (\mathrm{x}) ; \mathrm{RTR}=\log (\mathrm{x}+1)]$ prior to parametric statistical analysis. Body mass and RTR were analysed using a Linear Mixed Model (LMM) with $p \mathrm{CO}_{2}$, autotomy and time as fixed factors and tank and individual (id) as random factors in the model $P \sim$ time + autotomy $+p \mathrm{CO}_{2}+$ time $*$ autotomy + time ${ }^{*} p \mathrm{CO}_{2}+$ autotomy $* p \mathrm{CO}_{2}+$ time $*$ autotomy $* p \mathrm{CO}_{2}+(1 \mid$ id $)+(1 \mid$ tank $)$. Cumulative mortality was assessed using the same three fixed factors in the LMM with tank as a random factor. Relative 
growth was assessed visually by calculating the formulae [final grams wet mass - initial grams wet mass)/initial grams wet mass $\times 100$ ] (Gooding et al., 2009). Arm regeneration was analysed using a similar LMM but with two fixed factors $\left(p \mathrm{CO}_{2}\right.$ and time) and tank/id as random factors. As arm regeneration was expressed as proportional data, it was arcsine-square-root transformed prior to statistical analysis (Sokal and Rohlf, 1995). All LMMs were run in R (R Core Team, 2017) using the lme4 package (Bates et al., 2015) as fully saturated models (i.e. including all interactions between fixed effects) and the best model, as determined by AIC model selection (using the 'dropterm' function) was selected. In addition, the final model was checked by visual inspection of the residuals plot and the Q-Q normal plot. Mass-specific and whole-tissue lipid energy content in the pyloric caeca and gonads, and calcium content of the intact and regenerating arms, were analysed using a two-way ( $p \mathrm{CO} 2$ and autotomy) ANOVA as LMM was not appropriate given the sample sizes (i.e. two individuals per treatment replicate) and a single terminal measurement. The calcium content of the regenerating arms was compared between the two $p \mathrm{CO}_{2}$ treatments using a Student's t test. ANOVA and t-test analyses were conducted in SPSS v25.

\section{Results}

\subsection{Mortality}

Mortality increased with time (LMM, p<0.001; Table 2; Figure 2) with 20 starfish dead after 120 days. There was a significant interaction between autotomy and time (LMM, p=0.009; Table 2; Figure 2) with cumulative mortality higher amongst autotomised starfish (13 vs 7 starfish; Figure 2) although this was not significant $(\mathrm{p}=0.41)$. The LMM indicated a large tank effect on mortality (Table 2; see Figure 2). Individuals exposed to higher $p \mathrm{CO}_{2}$ showed a tendency of $33 \%$ reduction in cumulative mortality ( 8 vs 12 starfish) at the end of the experiment than individuals reared at ambient values.

\subsection{Body growth and arm regeneration}


3A) but autotomised individuals tended to have lower body mass over time than non-autotomised starfish (LMM, p=0.078; Table 2), even at the end of the experiment after partial arm regeneration. However, autotomized starfish reared under low $p \mathrm{CO}_{2}$ showed faster rates of relative growth from day 60 onwards (Figure 3B).

The rate of arm regeneration of starfish was relatively continuous over the 120 day exposure period (ca. $2.5 \%$ per week; LMM, $\mathrm{p}<0.001$; Table 2), with no overall effect of $p \mathrm{CO}_{2}$ or the size of the longest arm (Figure 4).

\subsection{Behaviour (Righting Time Response - RTR)}

The results of the LMM indicated that there was no effect of time, autotomy or $p \mathrm{CO}_{2}$ on the righting time responses (RTR) of starfish (all p>0.05; Table 2). RTR values tended to be higher among autotomised individuals at ambient $p \mathrm{CO}_{2}$ on days 30 and 60 but this was due to high variability in RTR values for individuals in one of the replicate tanks for this treatment (Figure 5). Apart from this, the four treatments all showed comparable ranges of individual RTR values on the five measurement times (Figure 5).

\subsection{Lipid content}

Lipid energy content in pyloric caeca were higher (ranging from $2.10 \pm 0.10$ to $3.01 \pm 0.15$ $\mathrm{kJ} \mathrm{mg}^{-1}$ ) than in the gonads (ranging from $1.14 \pm 0.12$ to $1.61 \pm 0.14 \mathrm{~kJ} \mathrm{mg}^{-1}$ ) in all treatments (ANOVA; tissue ( $p \mathrm{CO}_{2}{ }^{*}$ autotomy): $\mathrm{F}_{5,136}=45.03, \mathrm{p}<0.001 ; p \mathrm{CO}_{2:} \mathrm{F}_{1,136}=5.74, \mathrm{p}=0.018$; autotomy: $\mathrm{F}_{1,136}=0.003, \mathrm{p}=0.957$ ) (Figure 6A). The total lipid energy content estimated in the pyloric caeca (ranging from $7.22 \pm 1.73 \mathrm{~kJ}$ to $12.98 \pm 1.13 \mathrm{~kJ}$ tissue ${ }^{-1}$ ) was also higher than for the gonad (ranging from $0.23 \pm 0.11 \mathrm{~kJ}$ to $0.56 \pm 0.19 \mathrm{~kJ}^{\text {tissue }}{ }^{-1}$ ) in all treatments (ANOVA; tissue $\left(p \mathrm{CO}_{2} *\right.$ autotomy):

$275 \mathrm{~F}_{5,40}=35.01, \mathrm{p}<0.001 ; p \mathrm{CO}_{2}: \mathrm{F}_{1,40}=4.52, \mathrm{p}=0.04$; autotomy: $\mathrm{F}_{1,40}=0.001, \mathrm{p}=0.983$ ) (Figure 6B). 
Lipid energy content in the pyloric caeca $\left(\mathrm{kJ} \mathrm{mg}^{-1}\right.$ wet mass) and the whole tissue (kJ tissue

$27{ }^{1}$ ) were higher in the elevated $p \mathrm{CO}_{2}$ treatment when compared to ambient conditions, with no effect of autotomy (see Tukey test results in Figure $6 \mathrm{~A}$ and $\mathrm{B}$, respectively). There was no effect of $p \mathrm{CO}_{2}$ or autotomy on the lipid energy content in the gonads, expressed as either mass-specific or total tissue energy equivalents (see Tukey test results in Figure 6A and B, respectively).

\subsection{Calcium content}

The mean calcium content of the intact arms was not affected by $p \mathrm{CO}_{2}\left(\mathrm{~F}_{1,20}=0.70 ; \mathrm{p}=0.41\right)$ and autotomy $\left(\mathrm{F}_{1,20}=0.51 ; \mathrm{p}=0.48\right)$ and revealed a non-significant interaction between them $\left(\mathrm{F}_{1,20}=1.30 ; \mathrm{p}=0.27\right)$ (Figure $\left.7 \mathrm{~A}\right)$. The calcium content of the regenerating arms was also not affected by $p \mathrm{CO}_{2}\left(\mathrm{t}_{10}=0.76 ; \mathrm{p}=0.47\right)$, although the average values in individuals reared at higher $p \mathrm{CO}_{2}\left(5.89 \pm 6.12 \mu \mathrm{mol} \mathrm{Ca}{ }^{2+} \mathrm{mg}^{-1}\right.$ dry mass $)$ were $33 \%$ lower than those reared at ambient $p \mathrm{CO}_{2}$ $\left(8.84 \pm 6.52 \mu \mathrm{mol} \mathrm{Ca}{ }^{2+} \mathrm{mg}^{-1}\right.$ dry mass) (Figure 7B).

\section{Discussion}

The present study demonstrates that near future elevations in seawater $p \mathrm{CO}_{2}$ with associated changes in seawater carbonate chemistry had little effect on the rate of regeneration of autotomised arms and righting time in adult $A$. rubens. Similar responses were observed in the tropical starfish, Luidia clathrata exposed to $\sim 780 \mu \mathrm{atm} p \mathrm{CO}_{2}(\mathrm{pH} 7.8$ ) for a slightly shorter exposure time (97 days; Schram et al., 2011). In contrast, exposure of the brittlestar Amphiura filiformis to lower seawater $\mathrm{pH}$ levels ( $\mathrm{pH} 6.8,7.3$ or $7.7 ; 40$ days) caused autotomized arms to regenerate faster and to acquire more calcium compared with controls (pH 8.0) (Wood et al., 2008). However, seawater $\mathrm{pH}$ of 7.3 and associated undersaturated carbonate conditions had little effect on regeneration in another species of brittlestar, Ophiura ophiura, over a 6 week period (Wood et al., 2010), but a significant negative effect on arm regeneration in a polar species, Ophiocten sericeum (20 day exposure; 
compensate physiologically for the changes in seawater carbonate chemistry (Melzner et al., 2009;

Whiteley, 2011). The capacity for acid-base regulation and biomineralisation in adult echinoderms

is species-specific and appears to be greater in those species normally exposed to natural $\mathrm{CO}_{2}$

fluctuations (Byrne and Przeslawski, 2013; Dupont et al., 2010a). Echinoderms are generally poor compensators in terms of buffering changes in body fluid $\mathrm{pH}$ via acid-base regulation but sea urchins appear to be better than sea stars (Collard et al., 2013; Dupont and Thorndyke, 2012; Stump et al., 2012). Compensatory responses, however, may come at a cost and lead to a depletion in energy reserves (Wittman and Pörtner, 2013). Overall, the lack of an effect of elevated $p \mathrm{CO}_{2}$ on rates of regeneration in $A$. rubens could be related to the fact that all animals were fed regularly during the experiment ensuring that energy reserves were sufficient to fuel tissue accumulation and any compensatory responses (Lawrence, 2010). The longer term effects of both elevated $p \mathrm{CO}_{2}$ exposure and repeated autonomy events remain unknown, especially under conditions of limited food availability where reduced energy intake may limit the potential for compensation. Studies caeca were higher under elevated rather than ambient $p \mathrm{CO}_{2}$, but lipid energy content in the gonads was unaffected. In echinoderms, lipids accumulated from the diet are stored mainly as triglycerides in asteroid echinoderms over the reproductive cycle with gametogenesis occurring in $A$. rubens in September-March and spawning in April-June (Oudejans et al., 1979; Oudejans and van der Sluis, 1979a; Vevers, 1949). Previous studies have reported that lipids are translocated from the pyloric caeca to the gonads during their development in asteroid starfish (Lawrence and Lane, 1982; 
the accumulation of lipid reserves in the pyloric caeca during elevated $p \mathrm{CO}_{2}$ exposure in $A$. rubens in the current study could signify a shift in energy balance between cellular energy availability and energy consumption (De Coen and Janssen, 1997). It is possible that starfish exposed to elevated $p \mathrm{CO}_{2}$ were experiencing metabolic depression either to conserve energy reserves, as observed in the intertidal starfish Parvulastra exigua exposed to a $p \mathrm{CO}_{2}$ of $~ 750 \mu \mathrm{atm}(\mathrm{pH} 7.8$; McElroy et al., 2012), or as a response to the failure to maintain internal acid-base homeostasis (Pörtner, 2008), although juvenile $A$. rubens show no reduction in metabolic rate at low pH (Appelhans et al., 2014; Collard et al., 2013). However, it is also possible that regular feeding of the starfish enabled them to accumulate sufficient energy stores to support the costs of regeneration during exposures to near future $p \mathrm{CO}_{2}$ levels of $\sim 1000 \mu \mathrm{atm}$.

In the present study, growth of $A$. rubens expressed as changes in body mass was not affected by $p \mathrm{CO}_{2}$ or autonomy. Similarly, Schram et al. (2011) reported growth in adult tropical starfish Luidia clathrata was unaffected by similar levels of $p \mathrm{CO}_{2}$ exposure $\left(\mathrm{pH} 7.8, p \mathrm{CO}_{2} 780\right.$ $\mu \mathrm{atm})$ after 97 days following autotomy. In contrast, previous studies on adult A. rubens have reported reduced growth rates with increasing $p \mathrm{CO}_{2}$ (Appelhans et al., 2012; Keppel et al., 2015), however, these differences may be attributable to differences in experimental design and/or conditions between studies. Appelhans et al (2012) found no difference in growth at 650 (pH 8.06) and $1250 \mu \mathrm{atm}\left(\mathrm{pH} 7.84\right.$ ) after 70 days (as seen in our study after 60 days; see Figure 3 ) at $13^{\circ} \mathrm{C}$ but reduced growth at $3500 \mu \mathrm{atm}(\mathrm{pH}$ 7.36). Keppel et al. (2015) reported reduced growth after 70 days at $\mathrm{pH} 7.9$ compared to $\mathrm{pH} 8.1$ for adult $A$. rubens reared at $24^{\circ} \mathrm{C}$ (at the upper end of the thermal tolerance for the species) compared to $20^{\circ} \mathrm{C}$. Appelhans et al. (2014) reported $p \mathrm{CO}_{2-}$ dependent differences in growth $[650>1150>3500 \mu$ atm $(\mathrm{pH} 7.85>7.64>7.17)]$ of juvenile $A$. rubens in a long-term experiment $\left(39\right.$ weeks at $\left.9^{\circ} \mathrm{C}\right)$ but not until after 18 weeks of experimentation, although a follow-up short-term experiment observed differences in growth after 6 weeks under similar $p \mathrm{CO}_{2}$ conditions at $13^{\circ} \mathrm{C}$. In contrast, Gooding et al. (2009) report a positive effect of increased $p \mathrm{CO}_{2}$ on the growth of juvenile intertidal starfish, Pisaster ochraceus. This was 
attributed to the lack of a continuous calcified skeletal structure in this species, decreasing the relative amount of calcified tissue requiring the involvement of expensive re-calcification mechanisms during high $\mathrm{CO}_{2}$ exposure. Clearly the effect of elevated $p \mathrm{CO}_{2}$ on growth rates is variable among echinoderms in general, and among studies on the same species but may also be a result of differences in experimental protocols.

The degree of calcification of the regenerating arms was also unaffected by elevations in $p \mathrm{CO}_{2}$ in the present study as has been observed in previous ocean acidification studies on $A$. rubens (Appelhans et al., 2014; Keppel et al., 2015) and the tropical starfish Luidia clathrata (Schram et al., 2011). In contrast, the starfish Pisaster ochraceus exposed to $p \mathrm{CO}_{2}$ levels of $780 \mu \mathrm{atm}(\mathrm{pH}$ $7.79 / 12^{\circ} \mathrm{C}$ and $7.82 / 15^{\circ} \mathrm{C}$ ) for 70 days showed a decline in calcified material compared to $380 \mu$ atm $\left(\mathrm{pH} 7.85 / / 12^{\circ} \mathrm{C}\right.$ and $7.88 / 15^{\circ} \mathrm{C}$ ) (Gooding et al., 2009), while the brittlestar Amphiura filiformis exposed to acidified water at $\mathrm{pH} 7.7,7.3$ and 6.8 for 6 weeks exhibited elevated calcium carbonate content in the arms compared to $\mathrm{pH} 8.0$ (Wood et al., 2008). Therefore, although it appears that energy allocation into growth and calcification of the regenerating arms varies between echinoderm taxa, the evidence indicates that these processes can be maintained in $A$. rubens exposed to near future elevated $p \mathrm{CO}_{2}$ conditions. This is important since impaired regeneration of autotomised limbs could have ecological consequences resulting from impaired feeding and locomotion of the affected individuals (Barrios et al., 2008; Díaz-Guisado et al., 2016; Dominguez et al., 2016; Shaeffer, 2016).

In summary, the results of the present study indicate that the combined stressors of increased $p \mathrm{CO}_{2}$ and autotomy did not affect survival, body growth, arm regeneration, righting time or calcium content of adult individuals of the intertidal predatory starfish Asterias rubens during a 120 day exposure period. However, higher concentrations of lipids in the pyloric caeca under increased $\mathrm{pCO}_{2}$ suggest that reproductive investment may be compromised with long-term exposure. In addition, there was a tendency for mortality to be higher amongst autotomised starfish and calcification to be lower in starfish exposed to increased $p \mathrm{CO}_{2}$. Therefore, we recommend that 
future studies consider experiments with chronic or longer exposure than the present study to elucidate the capacity of $A$. rubens to cope with climate-driven environmental change.

\section{Acknowledgments}

We thank Berwyn Roberts for collecting the starfish and Dr James Brown for help with the laboratory work.

Funding: This work was supported by São Paulo Research Foundation (FAPESP) [grant numbers 2013/50197-5, AT/IDM; 2014/12879-0, WSF; 2015/02727-0, MNR) and the National Council for Scientific and Technological Development (CNPq) [grant number 309697/2015-8, AT).

\section{References}

Abramoff, M.D., Magalhaes, P.J., Ram, S.J., 2004. Image Processing with ImageJ. Biophotonics, $11,36-42$.

Anger, K., Rogal, U., Schriever, G., Valentin, C., 1977. In-situ investigations on the echinoderm Asterias rubens as a predator of soft-bottom communities in the western Baltic Sea. Helgol. Wiss. Meeresunters. 29, 439-459. http://doi.org/10.1007/BF01609982

Appelhans, Y.S., Thomsen, J., Opitz, S., Pansch, C., Melzner, F., Wahl, M., 2014. Juvenile sea stars exposed to acidification decrease feeding and growth with no acclimation potential. Mar. Ecol. Prog. Ser. 509, 227-239. http://doi.org/10.3354/meps 10884

Appelhans, Y.S., Thomsen, J., Pansch, C., Melzner, F., Wahl, M., 2012. Sour times: Seawater acidification effects on growth, feeding behaviour and acid-base status of Asterias rubens and Carcinus maenas. Mar. Ecol. Prog. Ser. 459, 85-97. http://doi.org/10.3354/meps09697

Barrios, J.V., Gaymer, C.F., Vasquez, J.A., Brokordt, K.B., 2008. Effect of the degree of autotomy on feeding, growth, and reproductive capacity in the multi-armed sea star Heliaster helianthus. J. Exp. Mar. Bio. Ecol. 361, 21-27. http://doi.org/10.1016/j.jembe.2008.03.016 
Bates, D., Maechler, M., Bolker, B., Walker, S. (2015). Fitting linear mixed-effects models using lme4. J. Stat. Softw. 67, 1-48. doi:10.18637/jss.v067.i01.

Browman, H.I., 2016. Applying organized scepticism to ocean acidification research. ICES J. Mar. Sci.73, 529-536. http://doi.org/10.1093/icesjms/fsw010

Byrne, M., Przeslawski, R., 2013. Multistressor impacts of warming and acidification of the ocean on marine invertebrates' life histories. Integr. Comp. Biol. 53, 582-96. http://doi.org/10.1093/icb/ict049

Calil, P., Rocha, R.M., Freire, C.A., Roper, J.J., 2009. The role of Asterina stellifera (Echinodermata: Asteroidea) as a predator in a rocky intertidal community in southern Brazil. Zoologia 26, 279-287. http://doi.org/10.1590/S1984-46702009000200010.

Collard, M., Catarino, A.I., Bonnet, S., Flammang, P., Dubois, P., 2013. Effects of $\mathrm{CO}_{2}$-induced ocean acidification on physiological and mechanical properties of the starfish Asterias rubens. J. Exp. Mar. Bio. Ecol. 446, 355-362. http://doi.org/10.1016/j.jembe.2013.06.003

De Coen, W.M., Janssen, C.R., 1997. The use of biomarkers in Daphnia magna toxicity testing. IV. Cellular Energy Allocation: a new methodology to assess the energy budget of toxicantstressed Daphnia populations. J. Aquat. Ecosyst. Stress and Recovery 6, 43-55. http://doi.org/10.1023/A:1008228517955

Díaz-Guisado, D., Gaymer, C.F., Brokordt, K.B., Lawrence, J.M., 2006. Autotomy reduces feeding, energy storage and growth of the sea star Stichaster striatus. J. Exp. Mar. Bio. Ecol. 338, 73-80. http://doi.org/10.1016/j.jembe.2006.06.037

Doney, S.C., Fabry, V.J., Feely, R.A., Kleypas, J.A., 2009. Ocean acidification: the other $\mathrm{CO}_{2}$ $\begin{array}{lllll}\text { problem. } & \text { Ann. } & \text { Rev. }\end{array}$ http://doi.org/10.1146/annurev.marine.010908.163834

Dupont, S., Havenhand, J., Thorndyke, W., Peck, L., Thorndyke, M., 2008. Near-future level of $\mathrm{CO}_{2}$-driven ocean acidification radically affects larval survival and development in the 
brittlestar Ophiothrix fragilis. Mar. Ecol. Prog. Ser. 373, 285-294. http://doi.org/10.3354/meps07800

433

434

435

Dupont, S., Lundve, B., Thorndyke, M., 2010a. Near future ocean acidification increases growth rate of the lecithotrophic larvae and juveniles of the sea star Crossaster papposus. J. Exp. Zool. Mol. Dev. Evol. 314B, 382-389. http://dx.doi.org/10.1002/jez.b.21342

Dupont, S., Ortega-Martínez, O., Thorndyke, M., 2010b. Impact of near-future ocean acidification on echinoderms. Ecotoxicology 19, 449-62. http://doi.org/10.1007/s10646-010-0463-6.

Dupont. S.T., Thorndyke, M.S., 2012. Relationship between $\mathrm{CO}_{2}$-driven changes in extracellular acid-base balance and cellular immune response in two polar echinoderm species. J. Exp. Mar. Biol. Ecol. 424-425: 32-37. http://doi.org/10.1016/j.jembe.2012.05.007

Feely, R.A., Doney, S.C., Cooley, S.R., 2009. Ocean acidification: present conditions and future changes in a high $\mathrm{CO}_{2}$ world. Oceanography 22, 37-47.

Findlay, H.S., Kendall, K.A., Spicer, J.I., Turley, C., Widdicombe, S., 2008. Novel microcosm system for investigating the effects of elevated carbon dioxide and temperature on intertidal organisms. Aquatic. Biol. 3, 51-62. http://doi:10.3354/ab00061

Freeman, S.M., Richardson C.A., Seed, R., 2001. Seasonal Abundance, Spatial Distribution, Spawning and Growth of Astropecten irregularis (Echinodermata: Asteroidea). Estuar. Coast. Shelf. Sci. 53, 39-49. http://doi.org/10.1006/ecss.2000.0758

Gooding, R.A., Harley, C.D.G., Tang, E., 2009. Elevated water temperature and carbon dioxide concentration increase the growth of a keystone echinoderm. Proc. Natl. Acad. Sci. U. S. A. 106, 9316-9321. http://doi.org/10.1073/pnas.0811143106

Held, M.B.E., Harley, C.D.G., 2009. Responses to low salinity by the sea star Pisaster ochraceus from high- and low- salinity populations. Invertebr. Biol. 128 381-390. http://doi.org/10.1111/j.1744-7410.2009.00175.x 
455 Hendriks, I.E., Duarte, C.M., Álvarez, M., 2010. Vulnerability of marine biodiversity to ocean acidification: A meta-analysis. Estuar. Coast. Shelf. Sci. 86, 157-164. http://doi.org/10.1016/j.ecss.2009.11.022

Hernroth, B., Baden, S., Thorndyke, M., Dupont, S., 2010. Immune suppression of the echinoderm Asterias rubens (L.) following long-term ocean acidification. Aquat. Toxicol. 103, 222-224. http://doi.org/10.1016/j.aquatox.2011.03.001

Hu, M.Y., Casties, I., Stumpp, M., Ortega-Martinez, O., Dupont, S., 2014. Energy metabolism and regeneration are impaired by seawater acidification in the infaunal brittlestar Amphiura filiformis. J. Exp. Biol. 217, 2411-2421. http://doi.org/10.1242/jeb.100024

Hu, M.Y., Lein, E., Bleich. M., Melzner, F., Stumpp, M., 2018. Trans-life cycle acclimation to experimental ocean acidification affects gastric $\mathrm{pH}$ homeostasis and larval recruitment in the sea star Asterias rubens. Acta Physiol. 224, e13075. http://doi.org/10.1111/apha.13075

IPCC, 2014. Climate Change 2014: Synthesis Report. Contribution of Working Groups I, II and III to the Fifth Assessment Report of the Intergovernmental Panel on Climate Change [Core Writing Team, Pachauri. R.K., Meyer, L.A. (Eds.)]. IPCC, Geneva, Switzerland.

Joly-Turquin, G., Dubois, P., Coteur, G., Danis, B., Leyzour, S., Le Menach, K., Budzinski, H., Guillou, M., 2009. Effects of the Erika oil spill on the common starfish Asterias rubens, evaluated by field and laboratory studies. Arch. Environ. Contam. Toxicol. 56, 209-220. http://doi.org/10.1007/s00244-008-9176-8

Kayal, M., Vercelloni, J., Lison de Loma, T., Bosserelle, P., Chancerelle, Y. Geoffroy, S., Stievenart, C., Michonneau, F., Penin, L., Planes, S., Adjeroud, M., 2012. Predator crown-ofthorns starfish (Acanthaster planci) outbreak, mass mortality of corals, and cascading effects on reef fish and benthic communities. PLoSONE 7, e47363. http://doi.org/10.1371/journal.pone.0047363 
479 Kelley, A.L., Lunden, J.J., 2017. Meta-analysis identifies metabolic sensitivities to ocean

480

481

482

483

484

485

486

487

488

489

490

491

492

493

494

495

496

497

498

499

500

501

502

503 acidification. Meta-analysis identifies metabolic sensitivities to ocean acidification. AIMS Environmental Science 4, 709-729. http://doi.org/10.3934/environsci.2017.5.709

Keppel, E., Scrosati, R., Courtenay, S.C., 2015. Interactive effects of ocean acidification and warming on subtidal mussels and sea stars from Atlantic Canada. Mar. Biol. Res. 11, 337348. http://doi.org/10.1080/17451000.2014.932914

Kleitman, N., 1941. The effect of temperature on the righting of Echinoderms. Biol. Bull. 80, 292298. http://doi.org/10.2307/1537716

Kroeker, K.J., Kordas, R.L., Crim, R.N., Singh, G.G., 2010. Meta- analysis reveals negative yet variable effects of ocean acidification on marine organisms. Ecol. Lett. 13, 1419-1434. http://doi.org/10.1111/j.1461-0248.2010.01518.x

Kroeker, K.J., Kordas, R.L., Crim, R.N., Hendriks, I.E., Ramajo, L., Singh, G.S., Duarte, C.M., Gattuso, J.P., 2013. Impacts of ocean acidification on marine organisms: quantifying sensitivities and interaction with warming. Global Change Biol. 19, 1884-1896. http://doi.org/10.1111/gcb.12179

Lawrence, J.M., Lane, P., 1982. The utilization of nutrients by post-metamorphic echinoderms, in: Jangoux, M., Lawrence, J.M. (Eds.). Echinoderm Nutrition. Balkema, Rotterdam, pp. 331372.

Lawrence, J.M., 2010. Energetics costs of loss and regeneration of arms in stellate echinoderms. Integr. Comp. Biol. 50, 506-514. http://doi.org/10.1093/icb/icq027

Lawrence, J.M. Larrain, A., 1994. The cost of arm autotomy in the starfish Stichaster-Striatus. Mar. Ecol. Prog. Ser. 109, 311-313. http://doi.org/10.3354/meps109311

Lawrence, J.M. Cowell, B.C., 1996. The righting response as an indication of stress in Stichaster striatus (Echinodermata, Asteroidea). Mar. Freshw. Behav. Physiol. 27, 239-248. http://doi.org/10.1080/10236249609378969 
Loh, K.S., Todd, P.A., 2012. Autotomy, arm regeneration and cannibalism in the seastar Astropecten indicus. Contrib. Mar. Sci. 2012, 163-168.

McElroy, D.J., Nguyen, H.D., Byrne, M., 2012. Respiratory response of the intertidal seastar Parvulastra exigua to contemporary and near-future pulses of warming and hypercapnia. J. Exp. Mar. Bio. Ecol. 416-417, 1-7. http://doi.org/10.1016/j.jembe.2012.02.003

Melzner, F., Gutowska, M.A., Langenbuch, M., Dupont, S., Lucassen, M., Thorndyke, M.C., Bleich, M., Pörtner, H.-O., 2009. Physiological basis for high $\mathrm{CO}_{2}$ tolerance in marine ectothermic animals: pre-adaptation through lifestyle and ontogeny?, Biogeosciences 6, 23132331. http://doi.org/10.5194/bg-6-2313-2009

Menge, B.A., Daley, B.A., Lubchenco, J., Sanford, E., Dahlhoff, E., Halpin, P.M., Hudson, G., Burnaford, J.L., 1999. Topdown and bottom-up regulation of New Zealand, rocky intertidal communities. Ecol. Monogr. 69, 297-330. http://doi.org/10.1890/00129615(1999)069[0297:TDABUR]2.0.CO;2

Nagelkerken, I., Connell, S.D., 2015. Global alteration of ocean ecosystem functioning due to increasing human $\mathrm{CO}_{2}$ emissions. Proc. Nat. Acad. Sci. 112, 13272-13277. http://doi.org/10.1073/pnas.1510856112

Oudejans, R.C.H.M, van der Sluis, I., 1979a. Changes in the biochemical composition of the ovaries of the seastar Asterias rubens during its annual reproductive cycle. Mar. Biol. 50, 255261. http://doi.org/10.1007/BF00394207

Oudejans, R.C.H.M, van der Sluis, I., 1979b. Storage and depletion of lipid components in the pyloric caeca and ovaries of the seastar Asterias rubens during its annual reproductive cycle. Mar. Biol. 53, 239-247. http://doi.org/10.1007/BF00952432

Oudejans, R.C.H.M, van der Sluis, I., van der Plas, A.J., 1979. Changes in the biochemical composition of the pyloric caeca of female seastars, Asterias rubens, during their annual reproductive cycle. Mar Biol. 53, 231-238. http://doi.org/10.1007/BF00952431 
529 Pearse, V., Pearse, J., Buchsbaum, M., Buchsbaum. R., 1987. Living Invertebrates. Blackwell Scientific Publications, Boston, Massachusetts.

531

Pierrot, D., Lewis, E., Wallace, D.W.R., 2006. MS Excel Program Developed for $\mathrm{CO}_{2} \mathrm{System}$ Calculations. ORNL/CDIAC-105a. Carbon Dioxide Information Analysis Center, Oak Ridge National Laboratory, U.S. Department of Energy, Oak Ridge, Tennessee. http://doi.org/10.3334/CDIAC/otg.CO2SYS_XLS_CDIAC105a

Pörtner, H.-O., 2008. Ecosystem effects of ocean acidification in times of ocean warming: a physiologist's view. Mar. Ecol. Prog. Ser. 373, 203-217. http://doi.org/10.3354/meps07768

Prowse, T.A.A., Sewell, M.A., Byrne, M., 2008. Fuels for development: evolution of maternal provisioning in asterinid sea stars. Mar. Biol. 153, 337-349. http://doi.org/10.1007/s00227$\underline{007-0809-7}$

Przeslawski, R., Byrne, M., Mellin, C,. 2015. A review and meta-analysis of the effects of multiple abiotic stressors on marine embryos and larvae. Global Change Biol. 21, 2122-2140. http://doi.org/10.1111/gcb.12833

R Core Team (2017). R: A language and environment for statistical computing. R Foundation for Statistical Computing, Vienna, Austria. https://www.R-project.org/

Ramsay, K., Kaiser, M.J., Richardson, C.A., 2001a. Invest in arms: behavioural and energetic implications of multiple autotomy in starfish (Asterias rubens). Behav. Ecol. Sociobiol. 50, 360-365. http://doi.org/10.1007/s002650100372 .

Ramsay, K., Bergmann, M., Veale, L.O., Richardson, C.A., Kaiser, M.J., Vize, S.J., Feist, S.W., 2001b. Damage, autotomy and arm regeneration in starfish caught by towed demersal fishing gears. Mar. Biol. 138, 527-536. http://doi.org/10.1007/s002270000487

Raymond, J.F., Himmelman, J.H., Guderley, H.E., 2004. Sex differences in biochemical composition, energy content and allocation to reproductive effort in the brooding sea star Leptasterias polaris. Mar. Ecol. Prog. Ser. 283, 179-190. http://doi.org/10.3354/meps283179 
Rodríguez, A. Hernández, J.C. Clemente, A.B.S., 2017. Effects of ocean acidification on juveniles sea urchins: Predator-prey interactions. J. Exp. Mar. Biol. Ecol. 493: 31-40. http://doi.org/10.1016/j.jembe.2017.04.005

Ross, P.M., Parker, L., Byrne, M., 2015. Transgenerational responses of molluscs and echinoderms to changing ocean conditions. ICES J. Mar. Sci. 73, 537-549. http://doi.org/10.1093/icesjms/fsv254.

Rubilar, T., Díaz de Vivar, M.E., Pastor de Ward, C.T., 2008. Biochemical composition of body compartments during the reproductive cycle of the starfish Allostichaster capensis in Patagonia, Argentina. Rev. Biol. Trop. 56, 351-360.

Shaeffer, C.M., 2016. The effects of autotomy and regeneration on the locomotion and behavior or brittle stars (Echinodermata: Ophiuroidea) of Moorea, French Polynesia. PeerJ Prepr. 4:e2471v1 http://doi.org/10.7287/peerj.preprints.2471v1

Schram, J.B., McClintock, J.B., Angus, R.A., Lawrence, J.M., 2011. Regenerative capacity and biochemical composition of the sea star Luidia clathrata (Say) (Echinodermata: Asteroidea) under conditions of near-future ocean acidification. J. Exp. Mar. Bio. Ecol. 407, 266-274. http://doi.org/10.1016/j.jembe.2011.06.024

Sloan, N.A., Aldridge, T.H., 1981. Observations on an aggregation of the starfish Asterias rubens L. in Morecambe Bay, Lancashire, England. J. Nat. Hist. 15, 407-418. http://doi.org/10.1080/00222938100770311

Sokal, R.R., Rohlf, F.J., 1995. Biometry: The principles and practice of statistics in biological research. W.H. Freeman, New York.

Stumpp, M., Wren, J., Melzner, F., Thorndyke, M.C., Dupont, S.T. 2011. $\mathrm{CO}_{2}$ induced seawater acidification impacts sea urchin larval development I: elevated metabolic rates decrease scope for growth and induce developmental delay. Comp. Biochem. Physiol. A. 160, 331340. http://doi.org/10.1016/j.cbpa.2011.06.022 
Stumpp, M., Hua, M.Y., Melzner, F., Gutowska, M.A., Doreyc, N., Himmerkus, N., Holtmann, W.C., Dupont, S.T., Thorndyke, M.C., Bleich, M., 2012. Acidified seawater impacts sea urchin larvae $\mathrm{pH}$ regulatory systems relevant for calcification. Proc. Natl. Acad. Sci. U.S.A. 109, 18192-18197. www.pnas.org/cgi/doi/10.1073/pnas.1209174109

Stumpp, M., Hu, M., Casties, I., Saborowski, R., Bleich, M., Melzner, F., Dupont, S., 2013. Digestion in sea urchin larvae impaired under ocean acidification. Nat. Clim. Chang. 3, 10441049. http://doi.org/10.1038/nclimate2028

Suckling, C.C., Clark, M.S., Peck, L.S., Cook, E., 2014. Experimental influence of pH on the early life-stages of sea urchins I: different rates of introduction give rise to different responses. Invertebr. Repr. Dev. 58, 148-159. http://doi.org/10.1080/07924259.2013.875950

Suckling, C.C. Clark, M.S. Richard, J., Morley, S.A. Thorne, M.A.S., Harper, E.M., Peck, L.S., 2015. Adult acclimation to combined temperature and $\mathrm{pH}$ stressors significantly enhances reproductive outcomes compared to short-term exposures. J. Anim. Ecol. 84, 773-784. http://doi.org/10.1111/1365-2656.12316

Torres, G., Gimenez, L., Anger, K., 2007. Effects of osmotic stress on crustacean larval growth and protein and lipid levels are related to life-histories: The genus Armases as a model. Comp. Biochem. Physiol. B Biochem. Mol. Biol. 148, 209-224. http://doi.org/10.1016/j.cbpb.2007.05.011

Vevers, H.G., 1949. The biology of Asterias rubens L.: Growth and reproduction. J. Mar. Biol. Assoc. U.K. 28, 165-187. http://doi.org/10.1017/S0025315400055272

Watts, S.A., Lawrence, J.M., 1990. The effect of temperature and salinity interactions on righting, feeding and growth in the sea star Luidia clathrata. Mar. Behav. Physiol. 17, 159-165. http://doi.org/10.1080/10236249009378765

Whiteley, N.M., 2011. Physiological and ecological responses of crustaceans to ocean acidification. Mar. Ecol. Prog. Ser. 430, 257-271. http://doi.org/10.3354/meps09185 
604

605

606

607

608

609

610

611

612

613

614

615

616

617

618

619

620

Whiteley, N.M., Suckling, C.C., Ciotti, B.J., Brown, J., McCarthy, I.D., Gimenez, L., Hauton, C., 2018. Sensitivity to near-future $\mathrm{CO}_{2}$ conditions in marine crabs depends on their $\begin{array}{llllll}\text { compensatory capacities for salinity change. Sci. Rep. } & \text { 8, } & 15639\end{array}$ http://doi.org/10.1038/s41598-018-34089-0

Wittman, A.C., Portner, H.-O., (2013). Sensitivities of extant animal taxa to ocean acidification. Nat. Clim. Chang. 3, 995-1001. http://doi.org/10.1038/NCLIMATE1982

Wood, H.L., Spicer, J.I., Lowe, D.M., Widdicombe, S., 2010. Interaction of ocean acidification and temperature; the high cost of survival in the brittlestar Ophiura ophiura. Mar. Biol. 157, 2001-2013. http://doi.org/10.1007/s00227-010-1469-6

Wood, H.L., Spicer, J.I., Widdicombe, S., 2008. Ocean acidification may increase calcification rates, but at a cost. Proc. R. Soc. B Biol. Sci. 275, 1767-1773. https://doi.org/10.1098/rspb.2008.0343

Wood, H.L., Spicer, J.I., Kendall, M.A., Lowe, D.M., Widdicombe, S., 2011. Ocean warming and acidification: implications for the Arctic brittlestar Ophiocten sericeum. Polar Biol. 34, 10331044. https://doi.org/10.1007/s00300-011-0963-8 


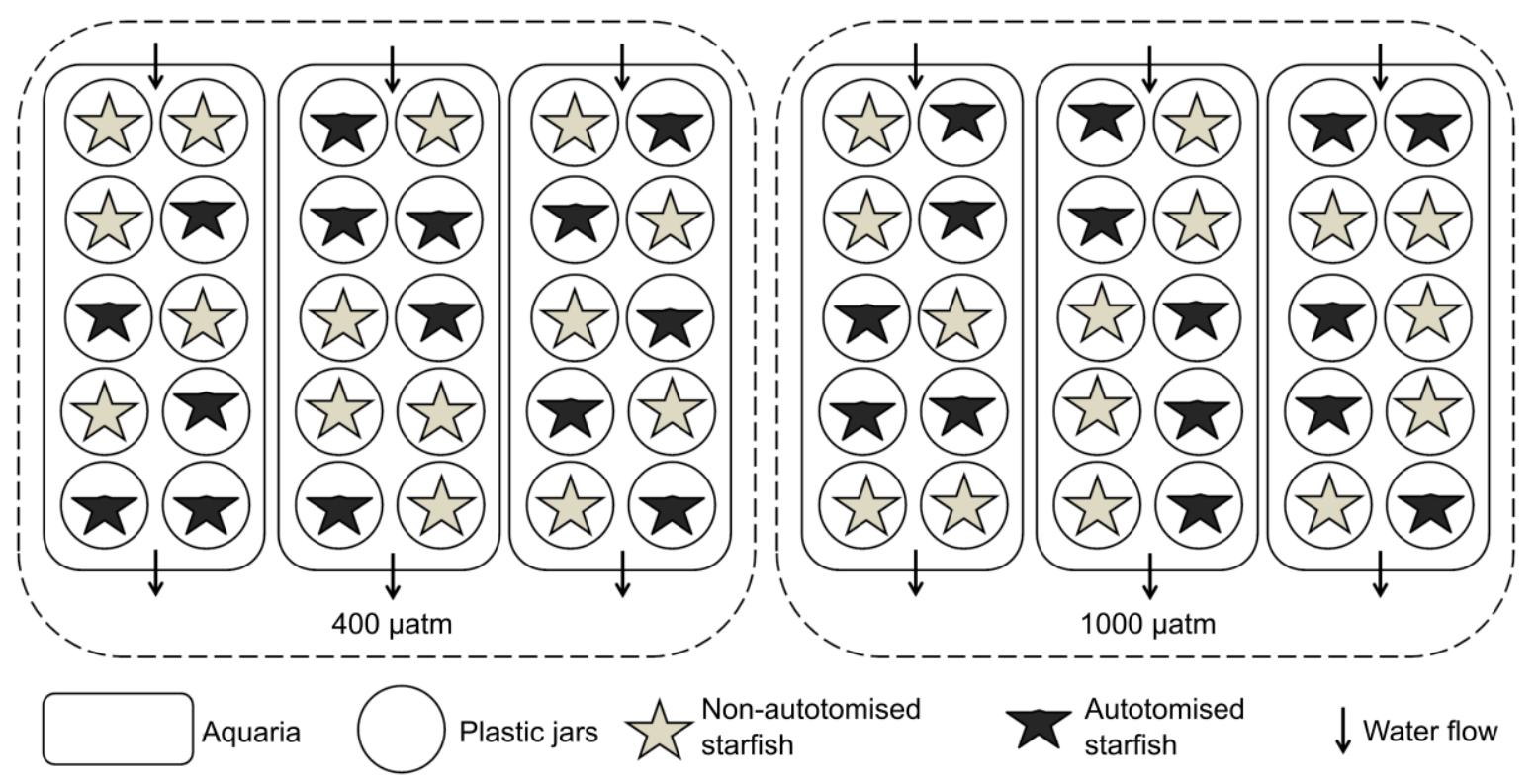

622

623 Fig. 1. Summary outline of the experimental aquarium design used in present study to determine

624 the impact of $p \mathrm{CO}_{2}$ control, $400 \mu \mathrm{atm}$; RCP 8.5 'business as usual', 1000 $\mu$ atm [IPCC, 2014])

625 and autotomy on Asterias rubens.

626 

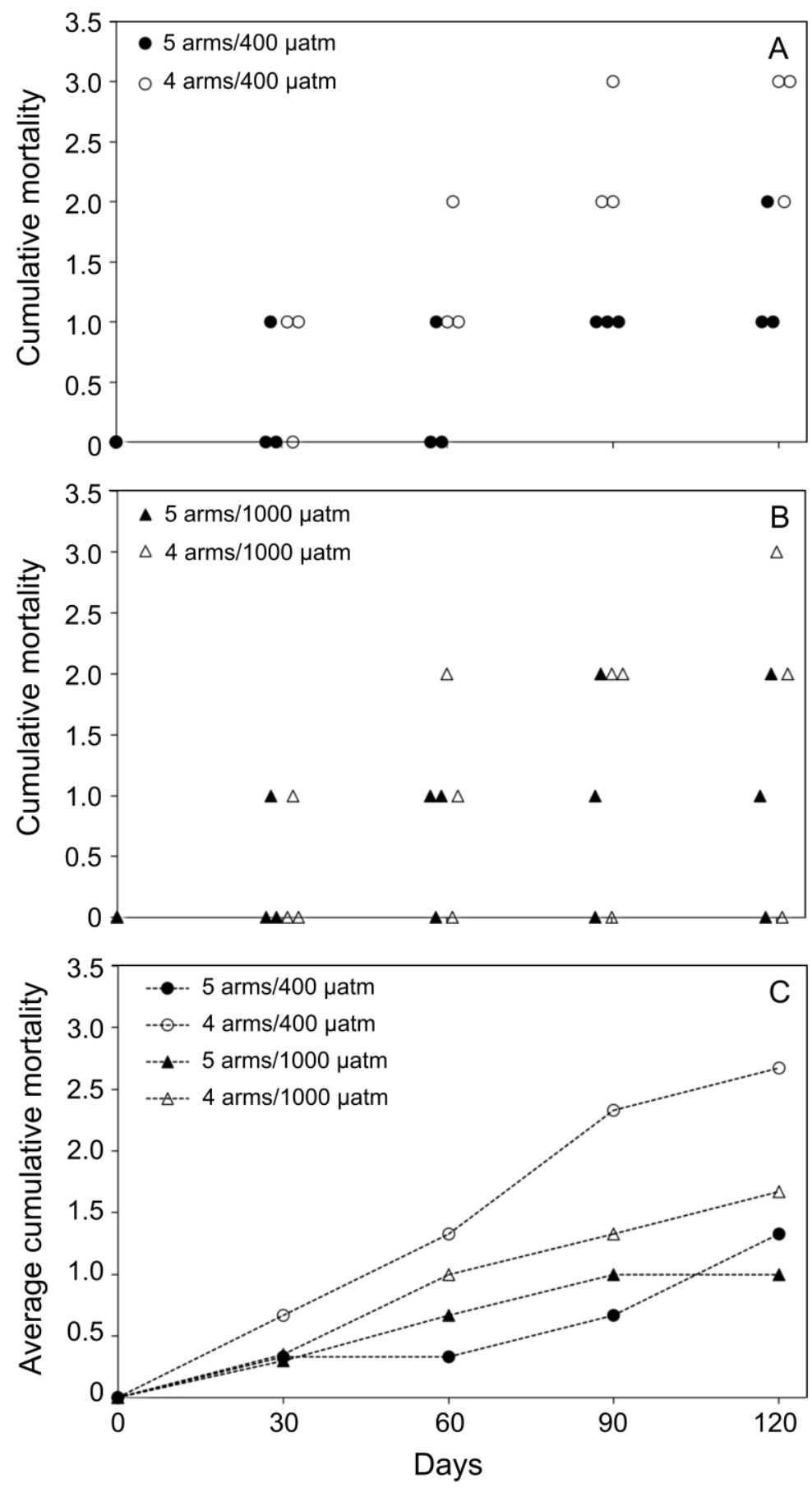

628 Fig. 2. Cumulative mortality (number of individuals) of autotomised (4 arms) and non-autotomised 629 (5 arms) Asterias rubens reared under different $p \mathrm{CO}_{2}$ levels: $\sim 400 \mu$ atm (control) and $\sim 1000 \mu \mathrm{atm}$ 630 (RCP 8.5 'business as usual', IPCC, 2014) for 120 days. Data are presented for cumulative mortality in replicate tanks of autotomised (4 arms) and non-autotomised (5 arms) Asterias rubens 632 reared at $(\mathrm{A}) \sim 400 \mu \mathrm{atm}$ and $(\mathrm{B}) \sim 1000 \mu \mathrm{atm}$ and $(\mathrm{C})$ average mortality per treatment. Data for 633 each replicate tank in (A) and (B) are slightly offset for clarity. 

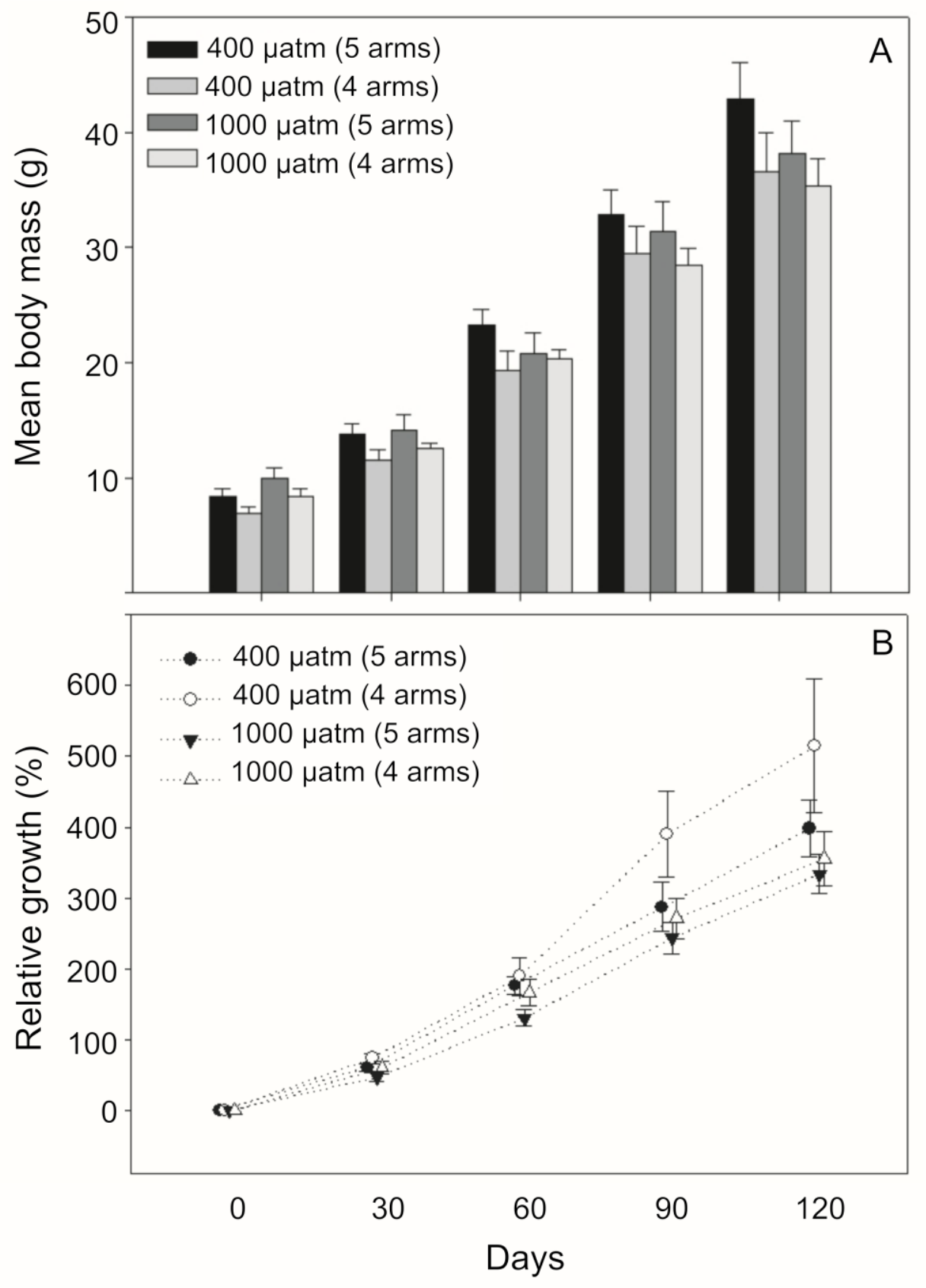

635 Fig. 3. (A) Body mass (g) and (B) percentage relative growth of autotomised (4 arms) and non636 autotomised (5 arms) Asterias rubens reared under different $p \mathrm{CO}_{2}$ level (control, 400 $\mu$ atm; $\mathrm{RCP}$ 6378.5 'business as usual', $1000 \mu \mathrm{atm}$ [IPCC, 2014]) for 120 days. (Data are presented as Mean \pm 638 1SE). 


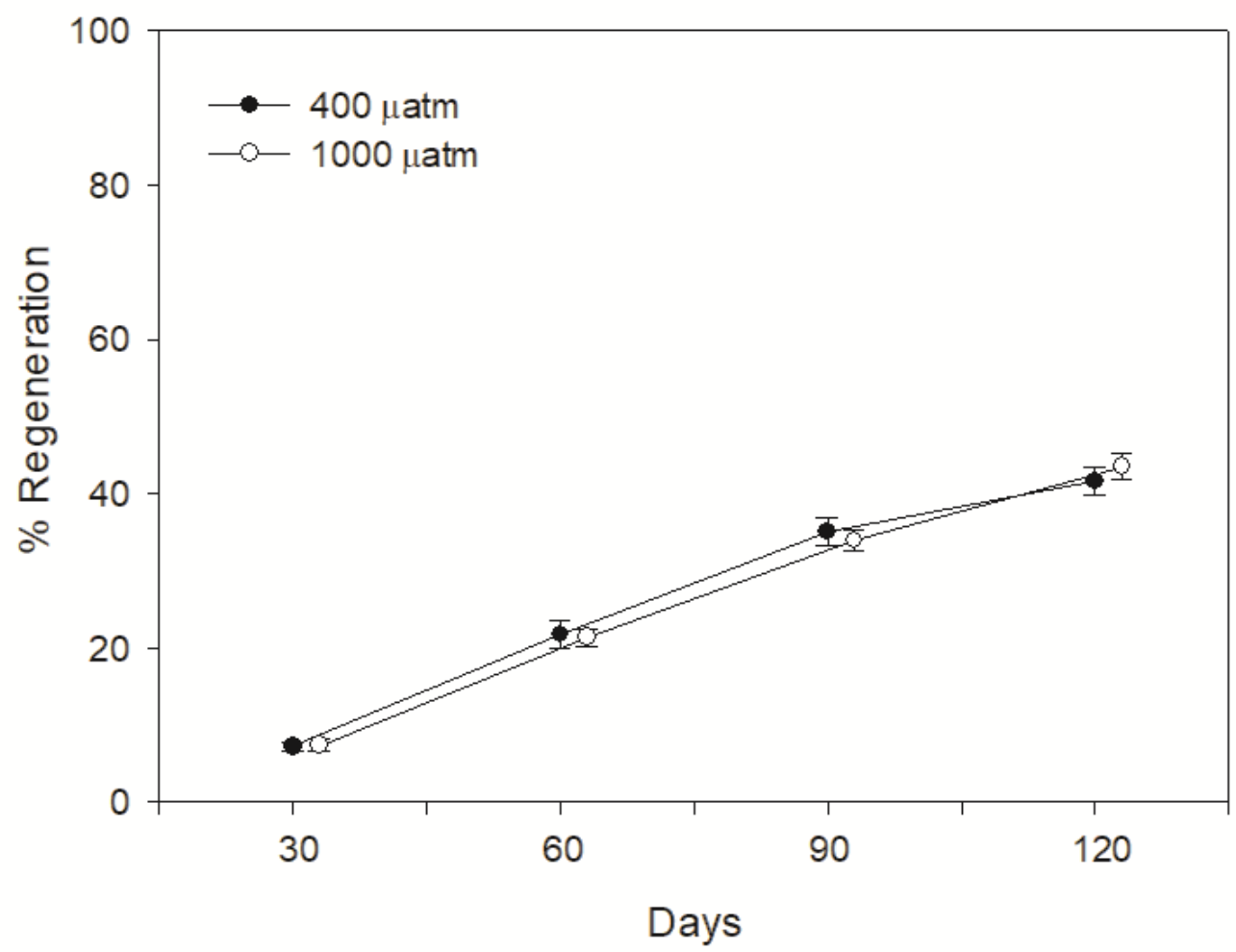

640

641 Fig. 4. Percentage regeneration of the autotomised arm of Asterias rubens reared under different $642 p \mathrm{CO}_{2}$ level (control, $400 \mu \mathrm{atm}$; RCP 8.5 'business as usual', 1000 $\mu$ atm [IPCC, 2014]) for 120 643 days. Percentage regeneration is calculated as $100 *$ (length of the regenerating arm/ length of the 644 longest arm) at each measurement. (Data are presented as Mean $\pm 1 \mathrm{SE}$ ). 

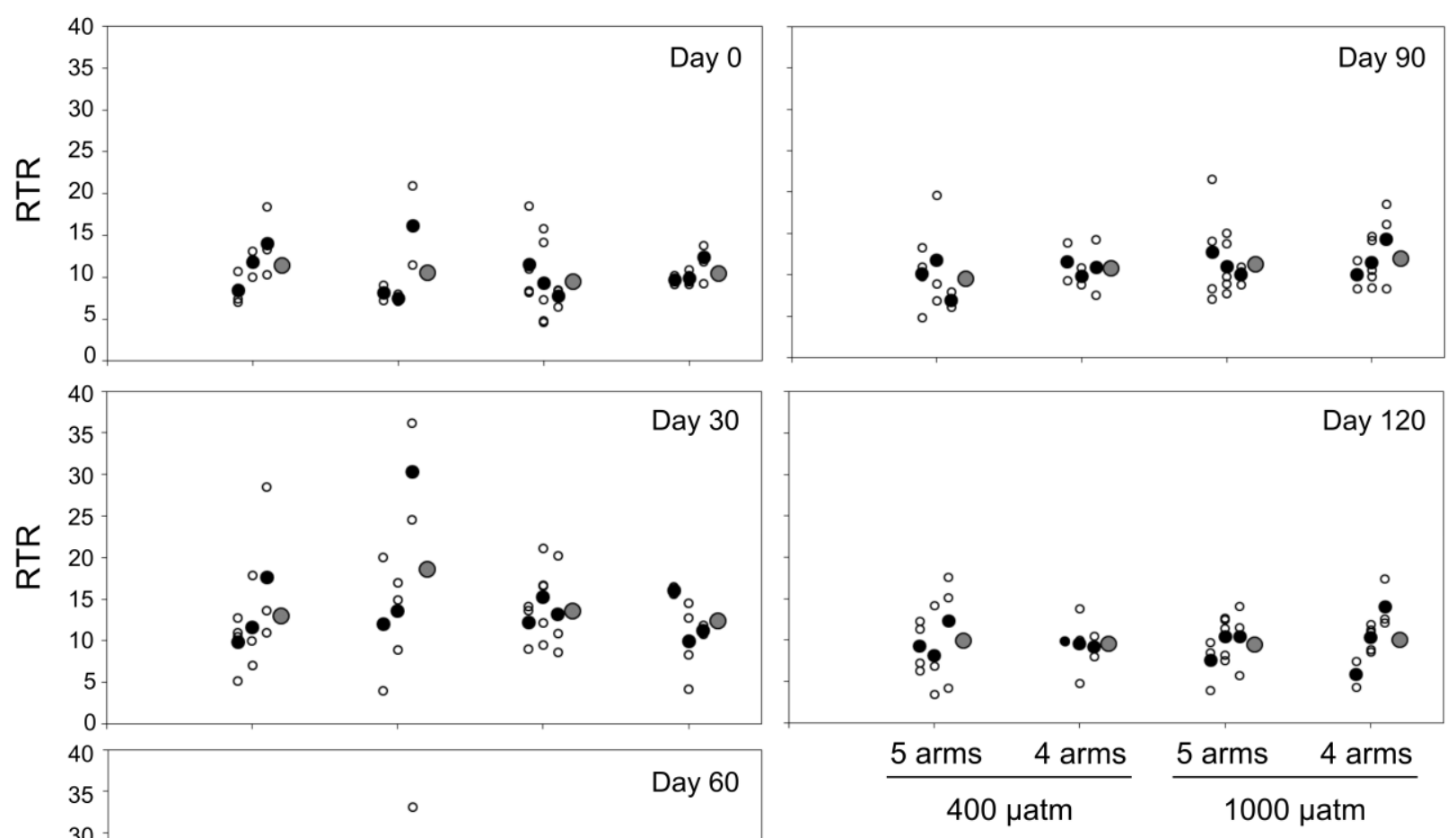

645

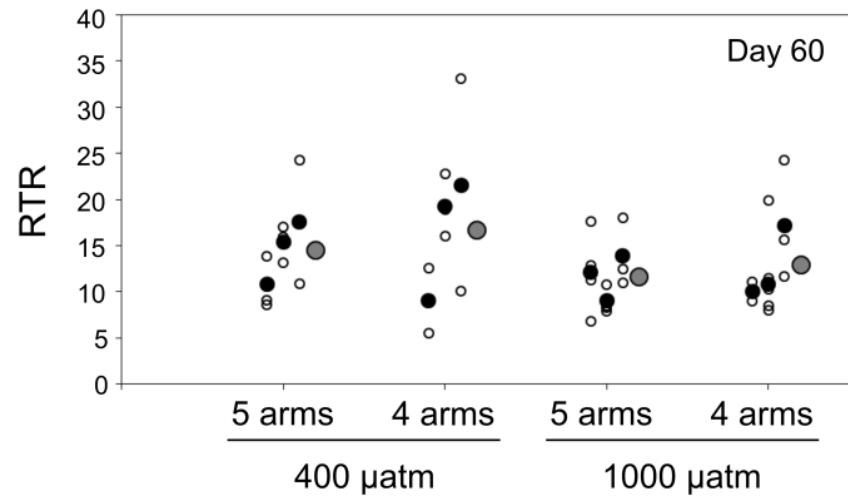

- Average for each replicate

Average for each treatment

646 Fig. 5. Righting time responses, expressed by the RTR value, of autotomised (4 arms) and non-

647 autotomised (5 arms) individuals of Asterias rubens reared under different $p \mathrm{CO}_{2}$ level (control,

$648 \sim 400 \mu \mathrm{atm}$; RCP 8.5 'business as usual', 1000 $\mu \mathrm{atm}$ [IPCC, 2014]) for 120 days. Data presented

649 are raw non-transformed data with statistical analyses conducted on log-transformed data (see

650 methods). For each treatment, open circles represent individual RTR values, filled black circles

651 represent the average RTR value for each replicate and the large grey filled circles represent the overall average value for each treatment. Data for each replicate tank are slightly offset for clarity. 

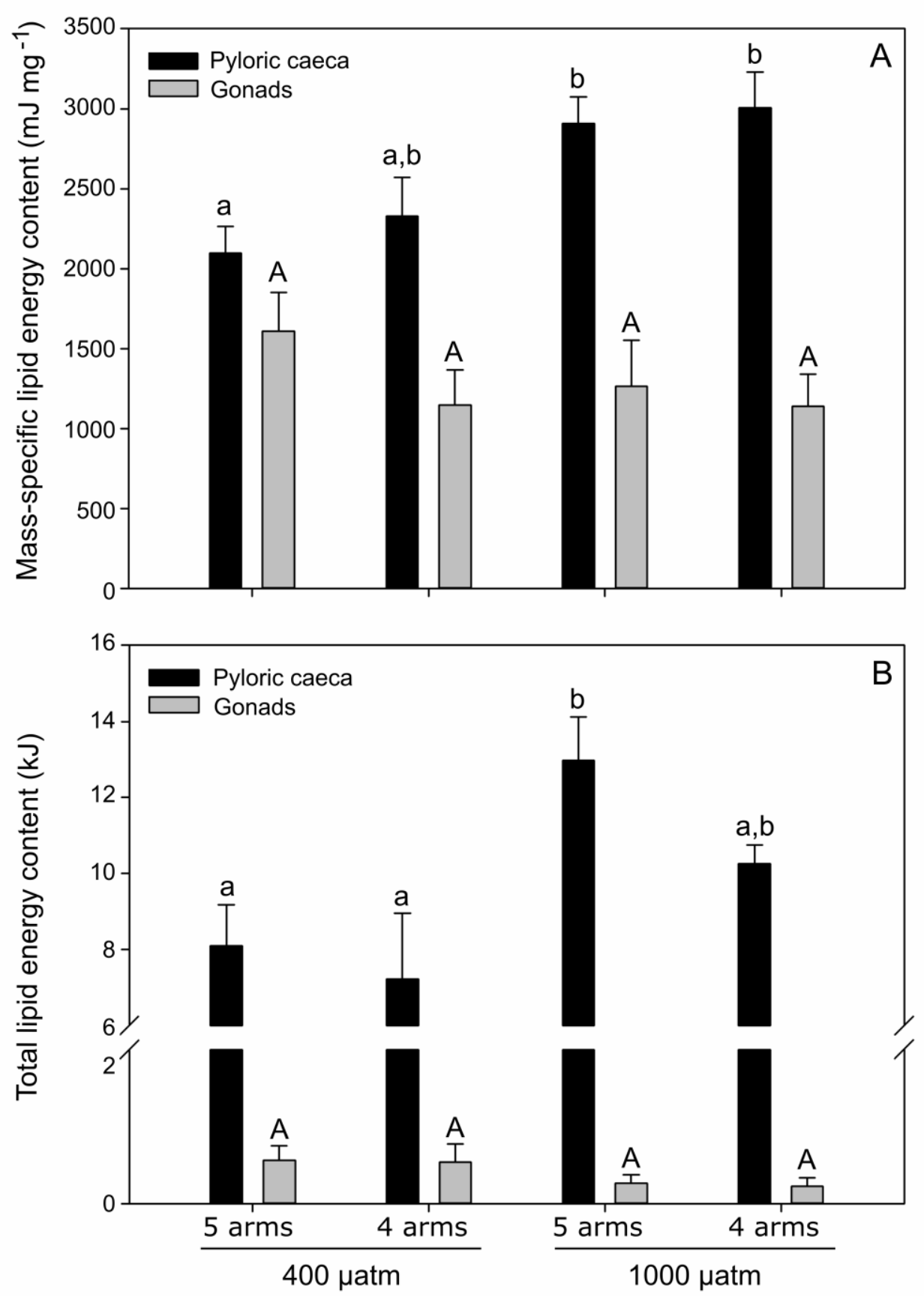

655 Fig. 6. (A) Mass-specific lipid energy content in the tissues ( $\mathrm{mJ} \mathrm{mg}^{-1}$ wet mass), and (B) total lipid 656 energy content $(\mathrm{kJ})$ in the tissues of autotomised (4 arms) and non-autotomised (5 arms) of Asterias 657 rubens reared under different $p \mathrm{CO}_{2}$ level (control, $\sim 400 \mu \mathrm{atm}$; RCP 8.5 'business as usual', 1000 $\mu$ atm [IPCC, 2014]) for 120 days. In (A) and (B), different letters indicate significant differences 659 (Tukey post hoc test) between treatments for gonads (upper case letters) and pyloric caeca (lower case letters), respectively. (Data are presented as Mean $\pm 1 \mathrm{SE}$ ) 

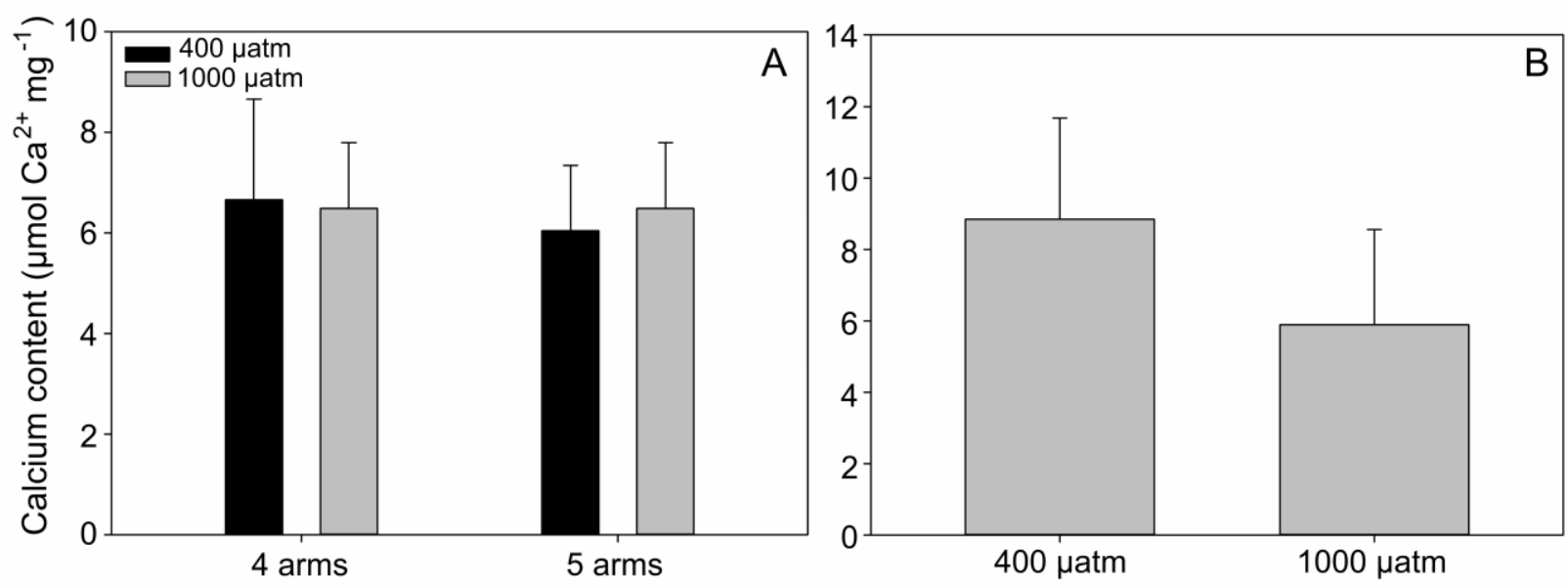

663 Fig 7. Calcium content, expressed in $\mu \mathrm{mol} \mathrm{Ca}^{2+} \mathrm{mg}^{-1}$ dry mass in the arms of Asterias rubens reared 664 under different $p \mathrm{CO}_{2}$ level (control, 400 $\mu \mathrm{atm}$; RCP 8.5 'business as usual', 1000 $\mu$ atm [IPCC, 665 2014]) for 120 days. Data are presented for (A) the left arm opposite to the position of the madreporite (i.e. the 'control' arm) of individuals subjected to arm autotomy (4 arms) or not (5 667 arms) and (B) in the regenerating arm of the individuals subjected to autotomy. (Data are presented 668 as Mean $\pm 1 \mathrm{SE})$.

669 
670 Tables

671 Table 1. Average seawater parameters for Asterias rubens reared under two different $p \mathrm{CO}_{2}$ levels

672 (control, $400 \mu \mathrm{atm}$; RCP 8.5 'business as usual', 1000 $\mu$ atm [IPCC, 2014]) for 120 days. Data

673 are presented as mean values \pm SE with associated $95 \%$ confidence interval (CI) range.

674

\begin{tabular}{lcccc}
\hline \multirow{2}{*}{ Parameters } & \multicolumn{2}{c}{ Control $(\mathbf{4 0 0} \mu \mathbf{\mu t m})$} & \multicolumn{2}{c}{ Experimental $(\mathbf{1 0 0 0} \boldsymbol{\mu a t m})$} \\
& Mean $\pm \mathbf{S E}$ & $\mathbf{9 5 \%} \mathbf{C I}$ & Mean $\pm \mathbf{S E}$ & $\mathbf{9 5 \%} \mathbf{C I}$ \\
\hline $\mathrm{pH}$ & $8.03 \pm 0.01$ & $8.02-8.05$ & $7.69 \pm 0.01$ & $7.67-7.72$ \\
Salinity & $32.86 \pm 0.07$ & $32.72-33.00$ & $32.97 \pm 0.06$ & $32.86-33.08$ \\
Temperature $\left({ }^{\circ} \mathrm{C}\right)$ & $12.4 \pm 0.04$ & $12.40-12.57$ & $12.38 \pm 0.04$ & $12.31-12.46$ \\
$\mathrm{TCO}_{2}\left(\mathrm{mmol} \mathrm{L}{ }^{-1}\right)$ & $1808 \pm 40$ & $1730-1886$ & $1867 \pm 40$ & $1789-1944$ \\
$p \mathrm{CO}_{2}(\mu \mathrm{atm})$ & $519 \pm 15$ & $490-550$ & $1070 \pm 30$ & $1011-1130$ \\
$\Omega_{\mathrm{CALC}}$ & $2.1 \pm 0.10$ & $1.90-2.24$ & $1.1 \pm 0.10$ & $0.97-1.23$ \\
$\Omega_{\mathrm{ARAG}}$ & $1.3 \pm 0.10$ & $1.21-1.43$ & $0.7 \pm 0.10$ & $0.62-0.79$ \\
\hline
\end{tabular}

675 
676 Table 2. Results of Linear Mixed Model used to test the fixed effects of time, autotomy and $p \mathrm{CO}_{2}$

677 and random effects of individual and tank on (A) mortality, (B) growth (body mass, g), (C) arm

678 regeneration (percentage regenerated), and (D) the righting time response (RTR) of Asterias rubens

679 reared under two different $p \mathrm{CO}_{2}$ levels (control, $\sim 400 \mu \mathrm{atm}$; RCP 8.5 'business as usual', 1000

$680 \mu \mathrm{atm}[$ [IPCC, 2014]) for 120 days.

\begin{tabular}{lcccc}
\hline Model component & $\begin{array}{c}\text { Estimate/ } \\
\text { *Variance }\end{array}$ & $\begin{array}{c}\text { Std Error/ } \\
\text { Std Dev* }\end{array}$ & $\mathbf{t}$ & Pr(>|t|) \\
\hline A) Mortality & -0.3000 & 0.2812 & -1.067 & 0.296 \\
Intercept & 0.3000 & 0.0688 & 4.363 & $<\mathbf{0 . 0 0 1}$ \\
Time & -0.2967 & 0.3225 & -0.827 & 0.412 \\
Autotomy & 0.2667 & 0.0972 & 2.742 & $\mathbf{0 . 0 0 9}$ \\
Time*Autotomy & 0.1861 & $0.4314^{*}$ & - & - \\
Tank & & & & \\
B) Growth & 1.7888 & 0.0664 & 26.932 & $<\mathbf{0 . 0 0 1}$ \\
Intercept & 0.3962 & 0.0087 & 45.373 & $<\mathbf{0 . 0 0 1}$ \\
Time & -0.1218 & 0.0668 & -1.822 & 0.078 \\
Autotomy & 0.0357 & $0.1891^{*}$ & - & - \\
id & 0.0103 & $0.1016^{*}$ & - & - \\
Tank & & & & \\
C) Arm Regeneration & 0.1559 & 0.0160 & 9.747 & $<\mathbf{0 . 0 0 1}$ \\
Intercept & 0.1466 & 0.0053 & 27.760 & $<\mathbf{0 . 0 0 1}$ \\
Time & 0.0008 & $0.0282^{*}$ & - & - \\
id & 0.0000 & 0.0000 & - & - \\
Tank & & & & \\
D) RTR & & & & \\
Intercept & 1.1321 & 0.0417 & 27.155 & $<\mathbf{0 . 0 0 1}$ \\
Time & -0.0122 & 0.0076 & -1.609 & 0.110 \\
Autotomy & -0.0248 & 0.0258 & -0.959 & 0.345 \\
$p$ CO ${ }_{2}$ & -0.0119 & 0.0437 & -0.272 & 0.431 \\
id & 0.0018 & $0.0428^{*}$ & - & - \\
Tank & 0.0019 & $0.0431^{*}$ & - & - \\
\hline
\end{tabular}

681 